\title{
Antibacterial effect of nanocomposites on the basis of various humic a veshchestvna the activator of ring rot of potatoes Clavibacter michiganensis ssp. sepedonicus
}

\author{
O.A. Nozhkina ${ }^{1 *}$, A.I. Perfilyeva ${ }^{1}$, I.A. Graskova ${ }^{1}$, B.G. Sukhov ${ }^{2}$ \\ ${ }^{1}$ Siberian Institute of physiology and biochemistry of plants of the SB RAS, Irkutsk, Russia \\ ${ }^{2}$ Irkutsk Institute of chemistry of A.E. Favorskii of the SB RAS, Irkutsk, Russia \\ *e-mail: alla.light@mail.ru,smallolga@mail.ru
}

Key words: silver nanocomposites, ring rot, humic substances, activity of peroxidase, bacteriostatic effect

Motivation and Task: The bacterial disease ring decay of potatoes caused by a bacterium of Clavibacter michiganensis SSP. Sepedonicus (Cms), has no ecologically safe measures of fight today. Bacteria extend on potatoes xylem vessels, form a biofilm, break water transport in the top part of a stalk, chlorosis leaves. It leads to a zavyadeniye - a typical symptom of a disease. Bacteria have ability to undergo winter conditions of the environment that gives them the chance to be transferred from generation to generation. All known means of protection come down to disinfecting by toxic substances. Need of development of ecologically safe means of fight against ring decay led to use of nanocomposites of silver based on the humic substances (HS) of various nature. HS have no toxicity, are steady, stimulate growth of plants and a pochvoobrazuyushchy biota, dyes, corrosion inhibitor, etc.

Methods and Algorithms: in a research were used As-1405 strain bacteria (it is received from the All-Russian collection of microorganisms, IBFM RAS), three types of the NC of silver packed into humid substances and their predecessors (NCHS - dirt/ $\mathrm{AgNO}_{3}, \mathrm{NCHS}-$ coals $/ \mathrm{AgNO}_{3}$, $\mathrm{NCHS}$ - slates $/ \mathrm{AgNO}_{3}$, HS - dirt, HS - coals, HS - slates and nitrate of silver) and potatoes plants which are grown up by grade in vitro Lukyanovskii. All substances were synthesized at the Irkutsk institute of chemistry by it A.E. Favorskii, they are readily soluble in water and their aqueous solutions are convenient to use. Studying of bactericidal effect of the NC and biofilm formation carried out by measurement of optical density of bacterial suspension. Plants incudated the $\mathrm{NC}$ and its predecessors, measured biometric indicators - a gain of plants, quantity of leaves, mass of roots and a land part, activity of peroxidase.

Results and Discussion: the bacteriostatic effect was shown by the predecessor of $\mathrm{AgNO}_{3} \mathrm{NC}$ which considerably suppressed growth of bacteria from the very beginning of the experiment. GV differently influenced the studied indicator. So, HS - $\mathrm{cl}$ and $\mathrm{HS}-\mathrm{sl}$ and their $\mathrm{NC}$ inhibited a gain of bacterial suspension and ability of a biofilm-formation in comparison with control, and $\mathrm{HS}-\mathrm{dt}$ and its $\mathrm{NC}$, on the contrary, stimulated reproduction of bacteria, and here reduced formation of biofilms. HS - cl stimulated biofilm formation of a bacterium of $\mathrm{Cms}$. After processing of plants of the $\mathrm{NC}$ and their predecessors, analyzed change of activity of protective enzyme - peroxidase in potatoes fabrics and a gain of plants. It was revealed that $\mathrm{AgNO}_{3}, \mathrm{HS}-\mathrm{dt}$, HS - sl, NCHS $\mathrm{dt} / \mathrm{AgNO}_{3}, \mathrm{NCHS}-\mathrm{sl} / \mathrm{AgNO}_{3}$ more than twice reduced activity of peroxidase. $\mathrm{HS}-\mathrm{cl}$ and NCHS $\mathrm{cl} / \mathrm{AgNO}_{3}$ rendered on activity of peroxidase of potatoes, as well as on biofilm formation of bacteria of $\mathrm{Cms}$ the stimulating influence. The received results demonstrate presence at some of the studied substances (NCHS - dt $/ \mathrm{AgNO}_{3}, \mathrm{NCHS}-\mathrm{cl} / \mathrm{AgNO}_{3}$ ) the bacteriostatic of properties and effect. Positive influence on plants characterized HS - sl and NCHS - sl/ $\mathrm{AgNO}_{3}$. Also, did not render the expressed negative effect on potatoes $\mathrm{NCHS}-\mathrm{dt} / \mathrm{AgNO}_{3}$. The submitted data confirm a possibility of use of the $\mathrm{NC}$ with silver nanoparticles for processing of cultural plants against bacterial diseases. Conclusion: studying of influence of the $\mathrm{NC}$ based on humic substances of various nature on the activator of ring decay of plants of Clavibacter michiganensis ssp sepedonicus potatoes. Showed, some $\mathrm{NC}$ and their predecessors can be the agents having the greatest antibacterial activity and not influencing potatoes plants that gives the grounds to judge their applicability as improving means against an activator strain without doing at the same time harm. All substances are available and easily applicable in use. The received result about influence of the NC on biofilm formation of $\mathrm{Cms}$ gives to us the grounds to use the NC as means of fight with phytopathogenic.

Acknowledgements: work is supported by a grant of the Russian Federal Property Fund and the Government of the Irkutsk region (project No. 17-416-380001). 